\title{
Adopting Physical Activities and Physical Skills of Japanese Early Childhood Model
}

\author{
Murni Ramli ${ }^{\mathrm{a}}$, Yudianto Sujana ${ }^{\mathrm{a}}$, Dyah Yuni Kurniawati ${ }^{\mathrm{a}}$, Matsuri $^{\mathrm{b}}$ \\ ${ }^{a}$ Center for Japanese Studies, Sebelas Maret University Surakarta, Indonesia \\ bepartment of Sports, Physical, and Recreational Education, Sebelas Maret University, Surakarta, Indonesia
}

Corresponding e-mail: mramlim04@fkip.uns.ac.id

\begin{abstract}
Routine and systematic physical activities which are focusing on development of physical skills have not been wellconsidered yet in our partner, Early Child care and Education (ECE) in Klaten, Central Java Indonesia. Instructors are mostly do not have sufficient knowledge on the importance of child physical activities and its relation to brain development. The Centre for Japanese Studies of Sebelas Maret University have tried to introduce a Japanese model of physical activities at ECEs since 2014, through annual workshop. After two years of practices, the perspective of instructors on physical activities are changed significantly, and trained instructors have challenged to develop animal mimic activities, which were adopted from Saito Kimiko's model, and put these as a regular morning program for children. In 2016, the theme of the workshop is practicing and assessing physical skills of children. 36 types of physicals exercises and 7 physical skills of Japanese model are introduced to 75 instructors from 21 ECE institutions in Klaten. Participants further learned and formulated cooperatively the adopted model. Questionnaire on perspective changes indicates that all participants stated the significant change before and after the training. Ten participants are selected to be interviewed on their perspective changes and action research about physical activities and physical skills of children.
\end{abstract}

Keywords: physical activities, physical skills, Japanese ECE

\section{INTRODUCTION}

Physical development of early child relates to quantitative growth of body size, cell organ number, organelle structure, and its functions. The growth and development of child physic also strongly associate to the ability of child to do some movements from simple to complex tasks.

The physical growth of early age children has been widely researched from various perspectives, and it found that many factors influence in, such as nutrient intake (Chow \& Humbert, 2011), daily physical activities of children at home (Temple, Naylor, Rhodes, \& Higgins, 2009) and school, activities at the nursery (Bower, et al., 2008) or it is also influenced by the instruction of teacher or instructors at ECE institution (Vanderloo, et al., 2014), the period of outdoor activities of children, and the playtime (Copeland, Kendeigh, Saelens, Kalkwarf, \& Sherman, 2012).

Physical activities of early-age children in Indonesia, practiced currently at child care or kindergartens are considered quantitatively and qualitatively low.
Instead of physical activities, a classroom based activities which focusing on children cognitive development, such reading, writing, and counting are the prominent. Otherwise, outdoor play time is relatively shorter than what applied in ECE Centre of advanced countries in the world, such as Japan.

The condition probably emerges due to the system of ECE in Indonesia, purpose and aim of ECE, perspective of parents and common people on what ideal children should be, cultural and religious effect, and the perception that cognitive are better than other aspects.

Early childhood Education in Indonesia consists of diverse day care centers and kindergarten, which can be divided as ones supervised by the Ministry of Education and Culture, and the ones under controlled of the Ministry of Religion Affairs. The last are focusing on strengthening on religious issues, such as worship and some doctrine of beliefs. It can be easily found at those day care or kindergartens, the very distinguished activities, such as learning on how to read the Quran, writing basic Arabic characters, memorising some readings for 
prayer, and practicing simple daily worship. Some sentences or readings for prayer and doctrine of beliefs are memorised. It can be memorised by singing, and playing.

Therefore, the time for practicing regular physical activities are becoming shorter, and not to be considered as the main activities at the ECE institution. Common perspectives of parents are also similar on how children should be nurtured. Most of them believe that children as early as possible have to learn doctrine of their belief and memorise readings on prayer or worship, in order to be a good devotee in their next life. Parent also force their kids to be able to read, write, and count, as they believed those are as the minimum qualification of entrance primary school. Though recent regulation released by the Ministry of Education and Culture calls to be revised and brought backed the concept of children development to the correct track, it does not directly nd easily change the mind set of parents and instructors of ECE.

To change the perspectives of ECE instructors on children physical development, and to reform the regular menu of physical activities in the ECE institution, critical and collaborative action research had been done in ECE schools in Karanganom County of Klaten District, Central Java Province Indonesia, in July to October 2016. We adopted the Japanese ECE concepts and strategies of physical activities as a pattern model. Japanese ECE is universally recognised as the one with excellent program on physical development of children. Our research on this topic had been started since 2013, and introduced the Japanese model and disseminated the Saito Kimiko's ECE physical activities to more than 900 instructors and student teachers of ECE in four regencies of Central Java (Ramli, 2014; Ramli, et al., 2015).

The purpose of this critical action research is to change and improve knowledge and practices on physical development, physical activities, and physical abilities of children, which traditionally understood as the non-important aspects by the ECE instructors at Karanganom County.

\section{LITERATURE REVIEW}

Physical activities in many cases are becoming the primary program of ECE in many countries as to prevent obesities and to guarantee healthy life among children (Taveras, et al., 2005; Story, Kaphingst, \& French, 2006). Some countries, such as Canada, USA, and UK have enacted a particular policy to obligate the ECE institutions and even primary schools in the country to have a minimum 60 minutes' physical activities for children (Payne, Townsend, \& Foster, 2013; Zhou, et al., 2014; Lanigan, 2014; LaRowe, et al., 2016).

Many papers write on relation between physical activities of early childhood to the brain and cognitive development of children (Victora, et al., 2010; Barham, Macours, \& Maluccio, 2013). Physical movement of children is also argued have a wide range of impacts, such as memory, executive functioning, learning, on-task behaviour, and academic achievement (Savina, Garrity, Kenny, \& Doerr, 2016).

To support physical activities and physical skills of children, specific program at ECE institution and at home should be introduced as a regular program, done daily. Furthermore, training and workshop to the ECE instructors, child care are suggested to be organised routinely. Early childhood educators play a main role in controlling the level and type of physical activities of children, therefore a sort of trainings, workshop and guideline have to be established as part of pre-service trainings of educator's candidate of ECE (Martyniuk \& Tucke, 2014). Changing the understanding and knowledge of child care belief on physical activities is argued as critical component on the success of obesity prevention (Lanigan, 2014).

Knowledge on physical movement and abilities of children is initial information that educators have to acquire. Infant and children at the certain age should indicate a special physical development. Four months to one-year-old infant is able to do reflective movements, which are actually the basic movement of human. These include reflect movement to sound, light, and touch. Year 1 to 2, children will show a rudimentary movement phase, in which child is able to control itself, such as doing a locomotor and manipulative activities, and starting to walk. They also try to always keep their toys close to them. And from 3 to 7 years old, children perform fundamental and specialised movements, for example running, jumping, kicking, throwing, and walking in balance on the bars (Gallahue \& Ozmun, 2006).

Japanese ECE system put physical activities of early age children as the main program which have to be applied at ECE institution. Daily activities of ECE nursery are mostly started at 8:30 or 9:00 o'clock in the morning, and ended in the different time. Some end at 10 o'clock, and the rest finished in the afternoon (around 4). The few number of day cares in the big city still open at night to help mothers who work until the late night.

One of the prominent practitioner on early childhood education in Japan is Saito Kimiko, which started her day care in 1956 in Saitama Japan, when she was 36 years old. She named her day care as 
Sakura Hoikuen. The main principle of physical activities at Saito Kimiko's day care is children have to be trained on the regular basis activities, which stressing on foot-especially tiptoe- and hand-based trainings. She had developed 43 types of physical exercises, which actually mimic the animal movements. There are four basics exercises that have to be daily trained to children from 0 to 5 years old. Each level of age will practice different exercises (Ramli, 2014; Ramli, et al., 2015).

Moreover, children in Saito Kimiko's day care also do daily activities as normal kids, such as playing, climbing the tree, taking bath, listening to the story telling, drawing, napping, eating, walking around, and for 4-5 years old children, they also do cleaning, sliding from the top of muddy hills, keeping goats or rabbits, reading, and helping to train their juniors. The training of physical exercises and daily activities of children at Sakura Hoikuen had been seriously researched by Koizumi Hideaki, a prominent neuroscientist of Hitachi Japan, and they both wrote outstanding Japanese books on physical activities and brain development of children (Saito \& Koizumi, 2008). Kazuhiko Nakamura introduced 36 basic exercises as fundamental measurement for physical abilities of children in Japan (Nakamura, et al., 2011). It was divided into three kinds activities, i.e. stability movements, locomotor movements, and manipulative movements.

\section{METHOD}

Research was done as an action research where 75 instructors from 21 ECE nurseries and kindergartens, joined as participants. Those ECE nurseries are the member of The Association of ECE Nursery (HIMPAUDI) of Karanganom, a county in Klaten Regency, Central Java Province, Indonesia. All participants were women, and have worked for 2 or more than 5 years. However, most of them graduated from non ECE Teacher Training College, but have followed some courses on ECE, organized by government or regional educational board. About 20 participants have followed the previous program on Introducing Saito Kimiko's Physical Activities, which was done on 2015.

The prior condition showed instructors did not have sufficient knowledge on physical activities of children, and mostly think cognitive skills more important than physical skills or there is no relation between physical development and cognitive development.

The action was a sort of training which combined between lecture and group workshop. The topic of the training is as shown in Table 1.
Table 1. The title of lectures and group workshop as action for changing the perspectives and knowledge of instructors.

\begin{tabular}{|c|c|c|}
\hline Meeting & Title & $\begin{array}{l}\text { Period } \\
\text { (mins) }\end{array}$ \\
\hline 1 & $\begin{array}{l}\text { Scientific view on children brain } \\
\text { development }\end{array}$ & 100 \\
\hline 2 & $\begin{array}{l}\text { Physic activities and physic } \\
\text { skills of early children in Japan }\end{array}$ & 100 \\
\hline 3 & $\begin{array}{l}\text { Physical development and } \\
\text { physical abilities of children }\end{array}$ & 100 \\
\hline 3 & $\begin{array}{l}\text { Instrument for assessing } \\
\text { physical abilities of children }\end{array}$ & 100 \\
\hline 4 & $\begin{array}{l}\text { Workshop of developing } \\
\text { instrument for assessing physical } \\
\text { abilities }\end{array}$ & 100 \\
\hline 5 & $\begin{array}{l}\text { Workshop of implementing } \\
\text { seven physical abilities }\end{array}$ & 100 \\
\hline 6 & Evaluation & 50 \\
\hline
\end{tabular}

The action research was held from June to September 2016. The questions that to be answered after the action research are: (1) What the prior perspectives of participants regarding the physical activities and physical development of early children; (2) Is there any perspective changing on physical activities, physical development, and physical abilities; and (3) In what extend participants absorbed the training content.

Knowledge and perspective of participants was measured pre-and post the action by questionnaire and interview. Ten participants were randomly selected to be interviewed regarding their perspective and concepts on early childhood physical activities.

The questionnaire consisted of 10 items of selfreflection, and eleven essay questions. The selfreflection aims to measure in which extend participants appraise themselves regarding some topics on children development before and after the training. Scale was ranged between 0 point to 100 point. Low category is 0 to 39 , middle or moderate category is between 40 to 69 , and high category is the rest (70-100).

\section{RESULT AND DISCUSSION}

\subsection{Prior Perspective on Physical Activities}

All participants appraised themselves as lack of knowledge and skills on how to do physical activities for early childhood and what benefits of physical activities as for cognitive development of children. As figured out in Table 2, the participants agreed that through the training, they had changed 
their mind set on the importance of physical activities.

Table 2. Participants' self-reflection on knowledge and skills about physical activities before the training

\begin{tabular}{|c|c|c|c|}
\hline \multirow[t]{2}{*}{ Question no. } & \multicolumn{3}{|c|}{$\begin{array}{l}\text { Self-reflection of } \\
\text { participant (\%) }\end{array}$} \\
\hline & Low & Mid & High \\
\hline 1. Physical development & 31.8 & 68.2 & 0 \\
\hline 2. Physical Abilities & 47.7 & 52.3 & 0 \\
\hline $\begin{array}{l}\text { 3. Relation of physical } \\
\text { dev, and cognitive dev. }\end{array}$ & 68.2 & 29.5 & 0 \\
\hline 4. Brain development & 50 & so & 0 \\
\hline $\begin{array}{l}\text { 5. Factors influence physic } \\
\text { development }\end{array}$ & 50 & so & 0 \\
\hline $\begin{array}{l}\text { 6. Instrument for assessing } \\
\text { physic development }\end{array}$ & 43.2 & 56.8 & 0 \\
\hline 7. Authentic assessment & 72.7 & 27.3 & 0 \\
\hline 8. Measuring physical dev. & 59.1 & 40.9 & 0 \\
\hline $\begin{array}{l}\text { 9. Assessing physic } \\
\text { abilities }\end{array}$ & 77.3 & 22.7 & 0 \\
\hline $\begin{array}{l}\text { 10. Exercises for training } \\
\text { physical abilities }\end{array}$ & 54.5 & 45.5 & 0 \\
\hline
\end{tabular}

Based on participants' self-reflection, knowledge on what relation between physical development and cognitive one, valued low by participants (68.2 percent). While, knowledge on authentic assessment, which is promoted as the prominent assessment in the 2013 Curriculum-a new curriculum for ECE in Indonesia- was also appraised low by 72.7 percent of participants.

In fact, about 68.2 percent of participants graded themselves as moderate in term of knowledge on physical development of early children. It is understandable since some participants had attended the previous training on Introducing Saito Kimiko's Physical Activities, which was held in 2014, by the team of Centre for Japanese Studies, Sebelas Maret University.

Knowledge on how to assess physics abilities of early children is the new topic for most participants. Therefore, about 77.3 percent of them assessed themselves as low understanding. Physics abilities of early children does not become regular assessment that instructors think to be put as the main indicator for children development.

Most of the participants understood that physical development of early children is important part of all development of human being, however, they are getting stuck when they just think the physical development is the physical growth of children, and it mostly categorised into two indicators, i.e. height and weight.

There were seven basic activities of Japanese early childhood physical abilities, which were introduced in this training, i.e. (1) running $25 \mathrm{~m}$, (2) jumping, (3) throwing a ball, (4) lifting body up, (5) jumping with two feet in the same distance sequences, (6) catching a ball, and (7) running on the certain track round trip (Figure 1).

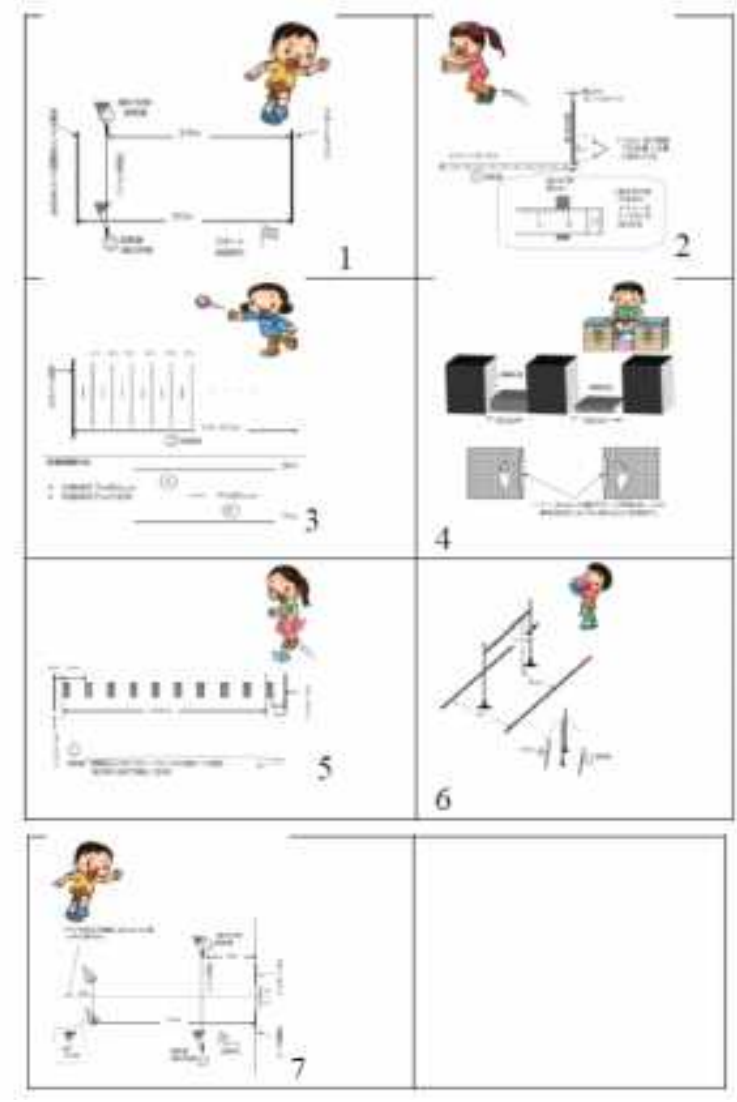

Figure 1. Seven basics physical activities in Japan according to MKS Youjiundounouryoku kenkyuukai (Mori, 2011)

Regular and systematic exercises for training children to develop their physical abilities seems known well by 45.5 percent of participants, and the rest accounted themselves as insufficient. In the preliminary survey, we found that so me ECE institutions do not have regular physical activities for early children. Some believes that physical training is identic with children running and playing during the break time. Only a small number of nurseries have regular motoric activities, such as what one participant who had already followed the previous training on Saito Kimiko's physical activities, said as follows: 
The are some physical skills trained in my nursery, particularly ones which related to fine motoric, such as wringing paper/wax, tearing paper, cut off with scissor, colouring, cutting, opening shirt, releasing shirt button, pinching up, clamping, and doing tassel. While we also train children on gross motoric, i.e. throwing and catching ball, crawling, climbing, hanging, walking on one foot, standing, running, jumping across the rope, and jumping from $30 \mathrm{~cm}$ height.

In fact, Japanese ECE nursery as Saito Kimiko's set up regular basic physical activities, which are daily and consistently applied in certain time and period, and in various movements depend on the age of children.

\subsection{Changing the Perspectives on Physical Abilities}

After being introduced and trained about Japanese model of early children physical activities, all participants appraised themselves in high level of understanding (Table 3 ). However, the average score ranges between 66.36 to 76.14 , or 71.82 as the average of group, while high category is 70 to 100 . It means, participants do not absolutely sure they understand well the content of trainings.

\begin{tabular}{cccc}
\hline $\begin{array}{c}\text { Question } \\
\text { no }\end{array}$ & \multicolumn{3}{c}{ Average Score* } \\
\hline 1 & Before & After & Point Up \\
\hline 2 & 37.5 & 75 & 37.5 \\
3 & 35.68 & 74.55 & 38.87 \\
4 & 30.68 & 70 & 39.32 \\
5 & 34.32 & 71.59 & 37.27 \\
6 & 35.23 & 76.14 & 40.91 \\
7 & 33.18 & 71.14 & 37.96 \\
8 & 31.59 & 66.36 & 34.77 \\
9 & 31.14 & 68.64 & 37.50 \\
10 & 28.64 & 70.23 & 41.59 \\
Total & 33.86 & 74.52 & 40.66 \\
\hline
\end{tabular}

"Minimum score: 0, Maximum score: 100

Table 3. Average score of self-reflection on physical abilities before and after the trainings
Participants rated themselves in the almost moderate category before the training, and increasing their understanding in less than 40 point after the training. This fact might indicate that participants need more details training and workshop on physical activities.

Changing the mind set and constructing the new concepts of ideal physical development of early children is not easy. It cannot be done by just asking instructors to attend a sort of training, but it need to also change the curriculum, daily activities, and deal with the theory of children development.

In order to practice the physical activities which are promoting physical abilities of early children, changing the knowledge and mind set of participants is inadequate. Additional training on skills to design physical activities, as well as to practice how to assess the process becomes more important.

All participants asked to have further training and monitoring for practicing physical activities and physical abilities measurement in their nurseries. The following statement can represent what they need:

This training was really worthwhile for us. We

hope that there will be direct mentoring, counselling, monitoring and evaluating from the team when we practicing the activities.

Further collaborating is need to be established between the Center for Japanese Studies as research group who consistently expand the idea of Japanese educational practices, with the ECE nurseries who joined the 2016 workshop.

\section{CONCLUSIONS}

Perspective of 75 instructors of ECE nurseries who joined the action research was appraised low according to self-reflection questionnaire, and have been changed into high level after the action research. Knowledge on what relation between physical development and cognitive development was relatively low, as well as the concept of physical abilities, how to conduct and how to assess regularly.

Participants rated themselves to be increase their knowledge in 38.64 points up after following the consecutive training on physical activities and abilities. This point indicates that the content of training has to be further flourished, along with rethinking the model of training, which is appropriate for all participants. Additional training and follow up have to be conducted to assist participants implement the physical activities at their own nurseries. 


\section{ACKNOWLEDGEMENTS}

This research was sponsored by The Community Services Grant of Sebelas Maret University (UNS), 2016 and The Center for Japanese Studies of UNS.

\section{REFERENCES}

Barham, T., Macours, K., \& Maluccio, J. (2013). Boys' Cognitive Skill Formation and Physical Growth: Long-Term Experimental Evidence on Critical Ages for Early Childhood Interventions. American Economic Review: Papers \& Proceedings, 103(3), 467-471.

Bower, J., Hales, D., Tate, D., Rubin, D., Benjamin, S., \& Ward, D. (2008). The childcare nvironment and children's physical activity. Am J Prev Med, 34, 23-29.

Chow, F., \& Humbert, L. (2011). Physical activity and nutrition in early years care centres: barriers and facilitators. Future Child, 36, 26-31.

Copeland, K., Kendeigh, C., Saelens, B., Kalkwarf, H., \& Sherman, S. (2012). Physical activity in child-care centers: do teachers hold the key to the playground? Health Educ Res, 27, 81-100.

Gallahue, D., \& Ozmun, J. (2006). Understanding Motor Development: Infants, Children, Adolescents, Adults. Boston: McGraw Hill.

Lanigan, J. (2014). Physical Activity for Young Children: A Quantitative Study of ChildCare Providers' Knowledge, Attitudes, and ealth Promotion Practices. Early Childhood Educ J, 42, 11-18.

LaRowe, T., Tomayko, E., Meinen, A., Hoiting, J., Saxler, C., \& Cullen, B. (2016). Active Early: one-year policy intervention to increase physical activity among early care and education programs in Wisconsin. BMC Public Health, 16, 607-616.

Martyniuk, O., \& Tucke, P. (2014). An exploration of Early Childhood Education students' knowledge and preparation to facilitate physical activity for preschoolers: a crosssectional study. BMC Public Health, 14, 727-736.

Mori, S. (2011). Yōji no undō nōryoku ni okeru jidai suii to hattatsu sokushin no tame no jissenteki kainyū. National Institute of Fitness and Sports in Kanoya. Kanoya: OnDemand Square.

Retrieved from MKS

Youjiundounouryokukensa: http://youjiundou. nifsk. ac.jp/determination/index.html

Nakamura, K., Takenaga, R., Kawaji, M., Kawazoe, K., Shinohara, T., Yamamoto, T., Miyamaru, M. (2011). Development of Fundamental motor pattern using the observational evaluation method in young children. Kyouiku Kaihatsu Kenkyuu, 1-18.

Payne, S., Townsend, N., \& Foster, C. (2013). The physical activity profile of active children in England. International Journal of Behavioral Nutrition and Physical Activity, 10, 136-143.

Ramli, M. (2014). Kajian Perbandingan Konsep Pendidikan Anak Usia Dini Model Saito Kimiko dan Yokomine Yoshifumi. Indonesian Journal of Japanese Studies, 213-235.

Ramli, M., Yudianto, S., Suciati, \& Riezky, M. (2015). Introducing Saito Kimiko`s Physical Activities for Stimulating Early Brain and Motor Development of Children. The Third International Conference on Early Childhood Education (pp. 100-104). Padang: Universitas Negeri Padang.

Saito, K., \& Koizumi, H. (2008). Noukagaku to nyuuyouji no sodachi. Tokyo: Furiidamu.

Savina, E., Garrity, K., Kenny, P., \& Doerr, C. (2016). The Benefits of Movement for Youth: a Whole Child Approach. Contemp School Psychol, 20, 282-292.

Story, M., Kaphingst, K. M., \& French, S. (2006). The role of child care settings in obesity prevention. The Future of Children, 16, 143-168.

Taveras, E.M., Rifas-Shiman, S.L., Berkey, C.S., Rockett, H.R.H., Field, A.E., Frazier, A.L., Colditz, G.A., Gillman, M. W. (2005). Family dinner and adolescent overweight. Obesity Research, 13, 900-906.

Temple, V., Naylor, P., Rhodes, R., \& Higgins, J. (2009). Physical activity of children in family child care. Appl Physiol Nutr Metab, 34, 794798.

Vanderloo, L., Tucker, P., Johnson, A., van Zandvoort, M., Burke, S., \& Irwin, J. (2014). The influence of centre-based childcare on preschoolers' physical activity levels: A crosssectional student. J Environ Res Public Health, 11, 1794-1802.

Victora, C. G., de Onis, M., Hallal, P., Blössner, M., \& Shrimpton, R. (2010). Worldwide Timing of Growth Faltering: Revisiting Implications for Interventions. Pediatrics, 125(3), e473-e480.

Zhou, Z., Ren, H., Yin, Z., Wang, L., \& Wang, K. (2014). A policy-driven multifaceted approach for early childhood physical fitness promotion: impacts on body composition and physical fitness in young Chinese children. MC Pediatrics, 14, 118- 130. 